\title{
CRITICISM AND REWORK OF HOMERIC NARRATIVE IN DIO'S TROJAN DISCOURSE
}

\author{
By Giampiero Scafoglio
}

Summary: Dio Chrysostom, in his Trojan Discourse (speech 11) rewrites the story of the Trojan War in a new and different way (with Trojans' victory over Greeks, the murder of Hector by Achilles, and so on), in contrast with the tale of the Iliad and under the pretense of an historical reconstruction. He preys on Homeric narrative techniques (such as the selective and motivated plot of the Iliad, and the first-person tale in the Odyssey), in order to disprove the traditional version of the legend and to pave the way for a new view. Dio takes a metaliterary and intertextual approach to Homeric epics, insofar as he criticizes and deconstructs their narratives (bearing in mind Homeric criticism by Aristotle and by Alexandrine grammarians), in order to rebuild the story anew. He also provides a specimen of generic crossing, since he frames an epic subject in the context of a prose speech that belongs to epidictic oratory and that simulates some historiographical practices.

The Trojan Discourse (speech 11) by Dio Chrysostom is a striking example of a 'critical' and 'creative' approach to the Trojan myth and Homeric epics, ${ }^{1}$ taking place against the background of the Second Sophistic with its corrosive criticism of the cultural tradition. ${ }^{2}$ Indeed, Dio rewrites the story of the Trojan War in a new and different way, in contrast with the

1 On Dio's profile as an intellectual and writer cf. Desideri 1978; Jones 1978; Amato 2014. The Trojan discourse is edited with Italian translation and an excellent commentary by Vagnone 2003, from which I quote.

2 On the innovative and 'polemical' reworking of Homeric themes in the cultural context of the Second Sophistic cf. Kindstrand 1973: esp. 13-44, 113-62; Zeitlin 2001; Favreau-Linder 2013; Briand 2015; Bär 2018. 
tale of the Iliad and under the pretense of historical objectivity. ${ }^{3}$ Evidently imitating Herodotus, he claims to have learned the true story from an Egyptian priest, who in turn found it written in the temples or heard it from an oral tradition handed down from generation to generation: it was Menelaus himself who disclosed the true events, when he came to Egypt after the war. ${ }^{4}$

In this speech, Dio examines some narrative techniques applied in the Homeric epics and tries to prove that they pursue a deceptive aim. In doing so, he conducts a narratological analysis (albeit in an embryonic form) of the Iliad and Odyssey. I will focus on Dio's arguments in order to show how he anticipates some approaches and methodological features of modern narratology and, at the same time, how he manipulates and even 'perverts' them, so to say, by interpreting Homeric techniques as deceptive strategies.

The rewriting of the Trojan legend is carried out in two phases: a pars destruens (a negative part with criticizing views, notably 1-37) and a pars construens (a positive part, stating a new position and arguments, 38-154). The pars destruens builds on the defamation of Homer as a poor wanderer accustomed to flattery and adulation because of his misery: a beggar and a liar for a living. Here Dio surprisingly and maliciously manipulates the same tradition on Homer's biography that he appreciated and praised elsewhere. ${ }^{5}$ Then he finds all the inconsistencies and contradictions that can be found in the Iliad and the Odyssey: the same inconsistencies and contradictions that Alexandrian grammarians had found and discussed at the time. ${ }^{6}$ Dio handles Alexandrian criticism (the issues and doubts

3 On Dio's reworking of the Trojan myth and Homeric epics in the Trojan Discourse cf. Kindstrand 1973: 141-62; Seeck 1990; Gangloff 2006: 122-36; Hunter 2009; Kim 2010: 85-139; Scafoglio 2016.

4 Cf. Dio, Tro. 37.2-38.7, taking the cue from Herodotus' $\lambda$ '́yo on Egypt (book 2 of the History) and in particular from his 'alternative version' about Helen, told by the Egyptian priests (2.112-20: Helen never went to Troy, but stayed in Egypt). On Herodotus' approach to the figure and myth of Helen: de Jong 2012; Saïd 2012.

5 Cf. Dio, Tro. 15-16, with Vagnone's commentary 2003: 116. Compare, for instance, the positive view of Homer's life and customs expressed by Dio in his speech 53 (esp. 9).

6 On Homeric criticism in the Hellenistic schools of thought and cultural currents cf. Pasquali 1952: 187-247; Montanari 1998: 1-17. On Dio's approach to this learned material: Vagnone 2003: 17-19. 
raised by ancient scholars about many Homeric episodes and passages) as evidence that the two poems are full of lies. ${ }^{7}$ In addition, and perhaps more importantly, Dio joins Plato's criticism of Homer's description of the gods (as he already did elsewhere, especially in his Olympic Discourse), ${ }^{8}$ merging the tool and the aim of the pars destruens. He claims that what Homes says about the gods, namely the unworthy feelings and actions that he attributes to them, absolutely cannot be true ${ }^{9}$. This is precisely the reason why Dio disproves and refutes Homer: he cannot accept the mythological view of the gods (with human faults and blemishes) belonging to religious and cultural tradition. ${ }^{10}$

The new and astonishing version of the Trojan legend established by Dio is mainly based on three points:

1) Paris did not abduct Helen: he was her lawful wedded husband; the Greek kings did not accept that the most beautiful girl in the world was married to a foreigner and organized the military expedition, with the real purpose to take over the great wealth of Troy.

2) Achilles did not kill Hector in the decisive duel: on the contrary, it was Hector who killed Achilles; but Homer told exactly the opposite in order to save the honor of the best Greek warrior. Indeed Homer put the (fake) murder of Patroclus by Hector in the place of the (true) murder of Achilles by Hector himself, and then he invented the story of the killing of Hector as Achilles' vengeance.

3) Troy was never conquered by the Greeks. On the contrary, the Trojans won the war and turned the Greeks away. However, at the end of the war, the two peoples were exhausted because of to the

7 Cf. Hunter 2009: 43, who concludes that "the whole project" of the Trojan discourse is "a distortion of a recurrent theme of ancient Homeric criticism", namely "the skillfulness and quality of Homer's lies".

8 Cf. Desideri 1980. On Plato's criticism to Homer's anthropomorphic description of the gods (esp. Resp. 3.398a-b): Murray 1996: 19-24; Cavarero 2002; Lacore 2003.

9 On Dio's criticism of Homeric religion in the Trojan Discourse (esp. 18), in the wake of Plato's remarks, cf. Scafoglio 2016: 457-59.

10 About Homer's authority in Greek religion, it suffices to recall Herodotus, 2.53, and Strabo, 8.3.30. On Dio's religious views, in general, cf. Desideri 2000; Van Nuffelen 2011: 84-90, 147-56. 
fighting and violence: thus, they established peace pacts and treaties, undertaking to never fight again.

The affirmation of these points is made possible by the defamation of Homer as a character and as a poet (based on the surreptitious interpretation of ancient Homeric biographies), and by the exposure of his narrative devices as a deceptive strategy. The latter expedient relies not only on Dio's critical approach to the myth and its specific arrangement in the epic tale, but also on the analysis of Homeric techniques that had previously been carried out at first instance by Plato and Aristotle, and secondarily by Alexandrian philologists.

Aristotle in the Poetics (1459a) praises Homer since "he did not make the whole war of Troy the subject of his poem, though that war had a beginning and an end: indeed the tale risked becoming too extended and not easy to embrace in an overall view"11 ( $\tau \tilde{\omega} \mu \eta \delta \delta \dot{\varepsilon} \tau o ̀ v ~ \pi o ́ \lambda \varepsilon \mu o v$

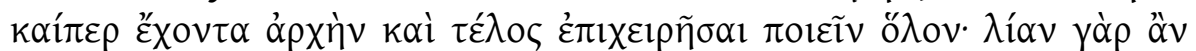

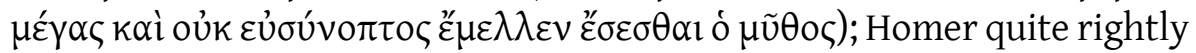
detached "a single portion" of the whole story ( $\tilde{\varepsilon} v \mu \varepsilon$ po $)$, improving consistency and narrative cohesion. ${ }^{12}$ Aristotle compares Homer's selective and coherent tale with the systematic and comprehensive accounts of the Trojan War provided by "other poets" (i.e. the poets of the Epic Cycle), who fashioned weak and fragmentary stories, "made up of several

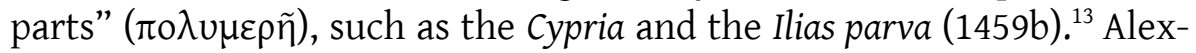
andrian scholars further develop Aristotle's criticism, but they overturn his judgement, questioning the reasons and results of Homer's arrangement of the tale, with particular attention to the beginning in medias res and the choice of subject matter. ${ }^{14}$ The Aristotelian tradition is well known to Roman scholars and poets, such as Horace, who in his Ars poetica states the need for a unitary and cohesive structure in literary works

11 All translations of Greek texts are mine unless otherwise stated.

12 Cf. Else 1957: 582-88. On Aristotle's judgement of Homer as the paradigm of epic poetry par excellence: Young 1983: 156-70; Richardson 1992: 30-40; Stroud \& Robertson 1996: 179-96.

13 For a reconstruction and interpretation of this problematic passage of Aristotle's Poetics cf. Scafoglio 2007: 287-98.

14 On the critical issue of the beginning of the Iliad cf. for instance the D-scholia ad Il. 1.1. On the Aristotelian background of Alexandrian criticism: Richardson 1994: 7-38. 
(1. 23, simplex dumtaxat et unum), mentioning Homer's poems as a positive example and the Epic Cycle as their negative counterpart (11. 136-152, nec sic incipies ut scriptor cyclicus olim: / 'Fortunam Priami cantabo et nobile bellum' etc.). ${ }^{15}$

Dio knows Aristotle's theory and the resulting critical tradition: he reworks such observations and even overturns their outcome, in order to devalue Homer's strategic choice and to reveal his true purpose, consisting in deceiving his audience. Indeed Homer, according to Dio, "did not start his tale right from the beginning, but from an event chosen at random, as almost all liars usually do, who with insertions and circum-

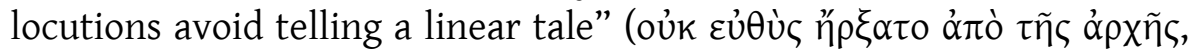

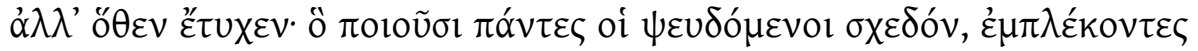

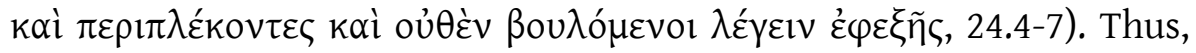
Dio points out Homer's selective approach to Trojan myth, in the wake of Aristotle and his later followers; but he interprets it as a tendentious expedient, a well-planned ruse aiming to exclude some 'inconvenient accidents' (viz. events that may reveal the truth) from the tale, and to deceive the audience: "otherwise the deception would be exposed by the

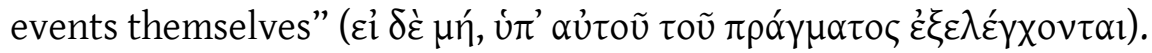

Dio accuses Homer of "deceptively reworking in particular the begin-

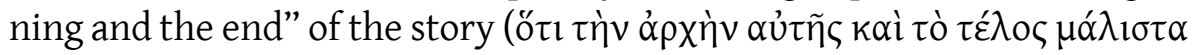
$\varepsilon \dot{\pi} \varepsilon \beta о u ́ \lambda \varepsilon v \sigma \varepsilon v, 25.5-6)$, since they are the hardest parts to manage in the re-elaboration of the myth. Indeed the beginning of the story covers the causes of the war, while the end affects the overall interpretation of the events. This is why Homer removes these parts and merely narrates a limited section of the war (26.1-4; 27.5-6):

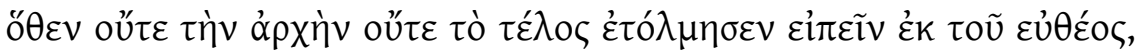

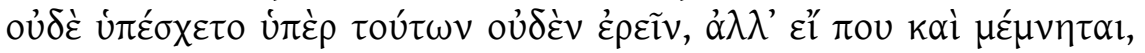

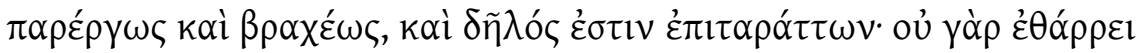

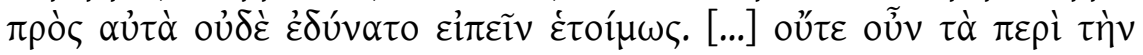

15 It is not clear whether Horace has a particular poem in mind (such as the Ilias Parva), or not. In any case, he refers to the comprehensive structure that was typical of the Epic Cycle and that is already criticized by Aristotle. Cf. Brink 1971: 213-14; Rudd 1989: 172; Fantuzzi 2015: 420-22. 


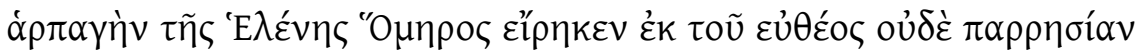

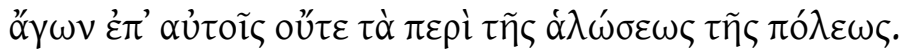

"For this reason he did not dare to tell neither the beginning nor the end in a straightforward way; nor did he promise to say anything about them, but if he mentions them anywhere, it is incidentally and briefly. It is evident that he is trying to confuse. Indeed, he was not at ease with respect to these parts and was unable to speak freely. [...] Homer did not talk in a clear and sincere way either about the abduction of Helen or about the fall of Troy."

Dio thus overturns Aristotle's judgement, with two remarkable consequences. On the one hand, the question arises as to what is the appropriate literary genre for the tale of the Trojan War. Dio (implicitly, but definitely) recognizes the primacy of history over poetry with respect to Aristotle's theory, under which history is concerned with actual events and implies the systematic and comprehensive account of such matter, while poetry deals with "general truths" (that means possible events and not real facts) and has a more flexible and creative approach to its subjects. ${ }^{16}$ Dio challenges the incompleteness of Homer's tale and claims the need of an exhaustive account of the Trojan War, under the principles of history. It is therefore not by chance that he rewrites the myth in prose and not in poetry, following Herodotus and Thucydides as models. He states that the Trojan War is a historical matter ${ }^{17}$ and, as such, belongs to historiographical genre. The Trojan Discourse is, in fact, a rework of Homer's tale in a (pseudo)historiographical form. ${ }^{18}$

16 On the difference between history and poetry (and the superiority of the latter on the former) according to Aristotle cf. Rosenmeyer 1982: 239-59; Heath 1991: 389-402; Carli 2010: 303-36.

17 Cf. e.g. 37.2-3: "I will give the account as I learned it from a very aged priest, one of

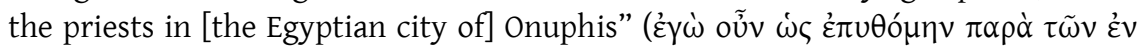

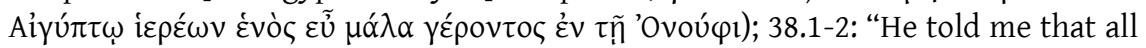
the history of earlier times was recorded in Egypt, in part in the temples, in part

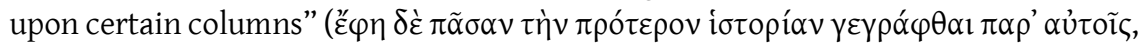

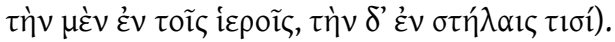

18 One might say that Dio reworks Homer's tale in the spirit of Herodotus, who was indeed considered "the prose Homer" since antiquity: Priestley 2014: 187-220. On the 
On the other hand, Dio corrects and even reverses Aristotle's judgement on the Iliad compared to the epic cycle. Dio deplores the inadequacy of Homer's tale and indirectly affirms the primacy of the Epic Cycle for precisely the same reason (selective approach to subject matter vs a comprehensive account), while Aristotle praises the former and devalues the latter. Moreover, Dio gives a sample of how an account of the Trojan War should be, reviewing the events of the conquest of Troy that would be a suitable subject for such a tale (29.3-30.4):

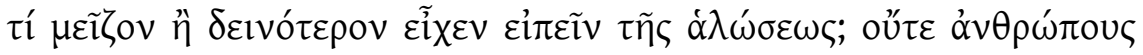

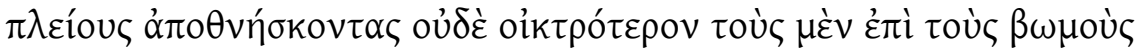

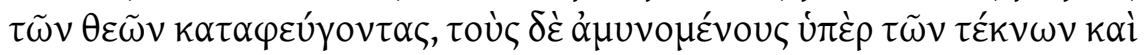

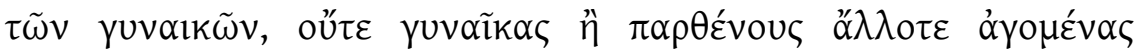

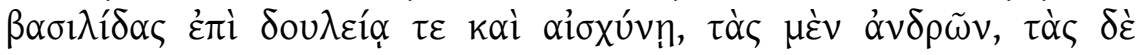

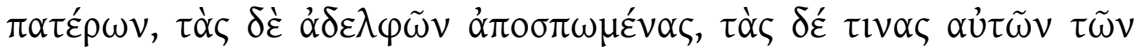

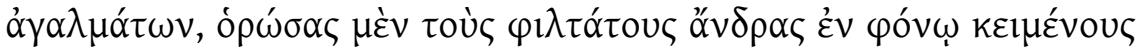

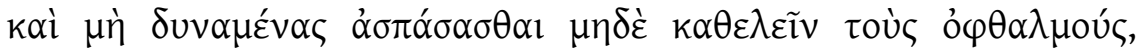

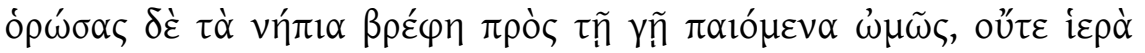

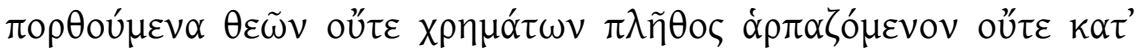

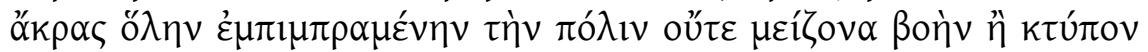

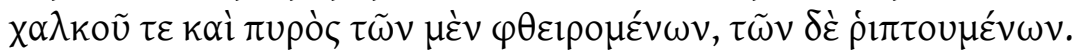

"What greater or more dreadful subject could he have chosen than the capture of the city? In no event a greater number of people died or more pitifully men fled to the altars of gods, or fought to save their children and wives; women and maidens of the royal family were dragged away to slavery and disgrace in foreign countries, some torn from their husbands, others from their fathers or brothers, and some even from the holy statues, while they beheld their beloved husbands lying in their blood without being able to embrace them or to close their eyes, and beheld their helpless kids thrown cruelly against the ground; and still, the desecration and looting of the temples of the gods, the plundering of a massive amount of wealth, the city burnt to the ground by the flames, the cries of agonizing men, the clash of

key role of Herodotus and Thucydides in Dio's speech cf. Hunter 2009: 43-61; Kim 2010: 85-190. 
bronze and the roar of the flames while some were perishing in them and others were being hurled upon them."

Actually, these are the same events that were covered by some poems of the Epic Cycle (as far as we can learn from fragments and evidence): Arctinus' Iliupersis and Lesches' Ilias parva.${ }^{19}$ However, Dio's purpose is not so much to rehabilitate the Epic Cycle, but rather to denounce Homer's deceptive strategy and, in general, the failure of his poem.

It should be noted, however, that this is not the only point on which Dio accuses Homer of hiding a part of the Trojan story in order to deceive the audience. He also criticizes the sudden interruption of scenes that would be decisive, if pursued to their supposed conclusion. Homer sometimes starts to recount a major event (mostly, a death match between two important warriors), but at some stage he interrupts the narrative on a pretext, without probable cause, in order to eclipse the true outcome (e.g. the murder of one of the two characters) and to continue his tale in an arbitrary and misleading way (82.1-83.3):

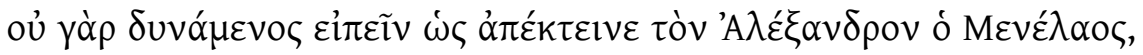

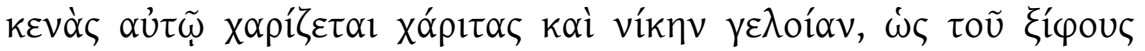

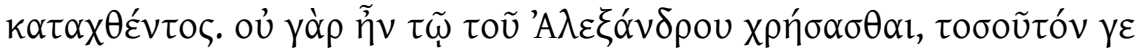

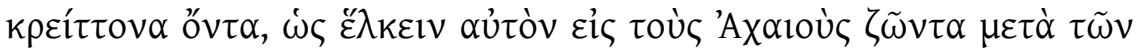

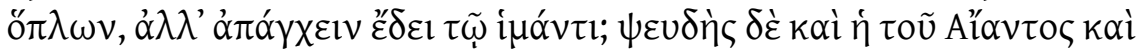

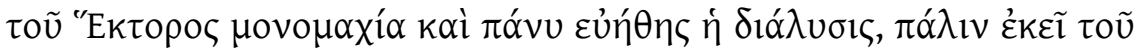

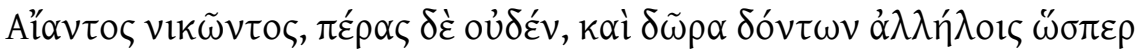

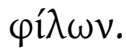

"Since Homer could not say that Menelaus killed Paris, he rewarded him with an empty honor and with a ridiculous victory by pretending that his sword broke. Was it impossible for him to use Paris's sword, given that he was strong enough to drag him alive with all his armor to the camps of the Achaeans? Did he have to choke him necessarily by the strap of his helmet? The duel between Ajax and Hector is also an invention, and its outcome is truly absurd. Here again Ajax takes

19 Fragments and evidence: Bernabé 1987: 71-92; Davies 1988: 49-66; West 2003: 118-52. Cf. Davies 1989: 61-76; Scafoglio 2017: 86-94. 
over, but there is no real result, and the two warriors offer gifts to one another as if they were friends!"

Dio refers to the duels between Menelaus and Paris (Il. 3.245-382) and between Ajax and Hector (7.181-312). Both duels have the potential to lead to major breakthroughs, with the victory of the Achaean warrior and the death of his Trojan opponent, but they are interrupted on flimsy grounds: the first one for the intervention of Aphrodite, who saves Paris just in time; the other one for the arrival of heralds who ask the warriors to stop the fight as the night is falling down (just when Ajax looms over Hector and is about to kill him).$^{20}$ Actually, this is a narrative technique, typical of the epic genre, developed to build a wide-ranging poem by means of preexisting mythological material that is originally passed on orally: some scenes fulfil a merely retarding function, raising and frustrating the expectations of the audience, in order to extend the tale (or rather to entertain the listeners for longer, in the oral perspective), without adding anything of any actual importance. ${ }^{21}$ Dio detects this technique, but he interprets it once again as a deceptive strategy.

However, the most remarkable expedient in the narrative economy of the Iliad, according to Dio, is the invention of the character of Patroclus as a "double" of Achilles (102.5-8):

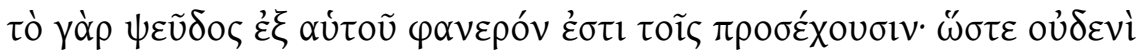

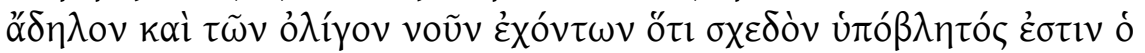

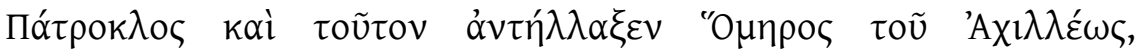

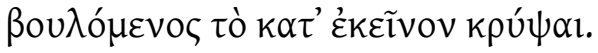

"The falsehood is self-evident to any careful observer, so much so that anyone with a modicum of intelligence can realize that Patroclus is a fictional character that Homer has substituted for Achilles in order to hide the truth concerning the latter."

Dio argues that, in reality, Hector killed Achilles in a death match; but Homer invented the character of Patroclus who acts as a "substitute" of

20 On this scene cf. Scafoglio 2017: 31-35.

21 Cf. Kirk 1990: 15-27; Edwards 1992: 284-330; Rengakos 1999: 308-38. 
Achilles. Thus, in the seeming fake tale of the Iliad (notably in book 16), Hector kills Patroclus instead of Achilles (103.6-104.5):

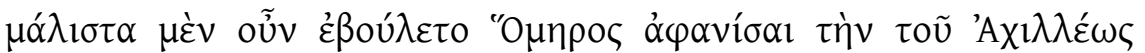

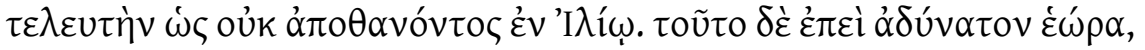

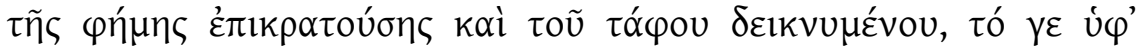

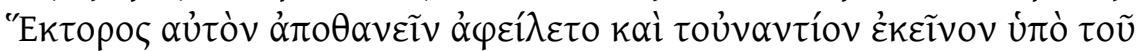

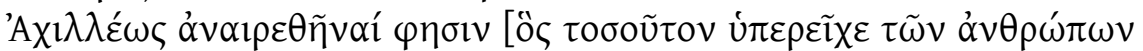

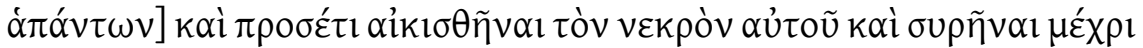
$\tau \tilde{\omega} \nu \tau \varepsilon\llcorner\chi \tilde{\omega} \nu$.

“Homer's primary purpose was to hide the murder of Achilles, pretending that he had not died at Troy; but he saw that it was not possible, since the rumour prevailed and his tomb was pointed out by the people. Then Homer suppressed the account of his death by Hector's hand and told, on the contrary, that the latter [who was so far superior to all other warriors] was slain by Achilles and even that his corpse was dishonored and dragged as far as the walls."

Dio comprehends the nature of Patroclus as a character complementary and even subordinate to Achilles: as a matter of fact, Patroclus is considered as a sort of "double" or "other half" of Achilles by many modern scholars, who regard him as a new or "added" character, invented by Homer and not originally coming from the myth. ${ }^{22}$ Dio's brilliant insight is to turn the advisor and helper (whether or not created by Homer) into a stand-in for Achilles. ${ }^{23}$ Patroclus plays a crucial role in the plot of the Iliad, as a main cog in the narrative machine, so to say, since his murder by Hector's hand unblocks the situation and resolves the impasse caused by Achilles' anger. Dio realizes that the narrative structure of the Iliad

22 The idea that Patroclus is invented by Homer or at least that his role is enhanced to fit the plot of the Iliad is argued with different reasoning and wording by Schadewaldt 1951: 178-81; Kullmann 1960: 44-45, 193-94; Dihle 1970: 159-160; Erbse 1983.

23 Arnould 1990: 187-89 seems to follow Dio's interpretation, suggesting that "la mort de Patrocle est le substitut de la mort d'Achille." 
does not work without Patroclus: he brands this character as a surreptitious invention in order to delete him from the story and to destroy Homer's plot construction.

Dio shows that he possesses a high degree of awareness regarding the narrative peculiarities of the Iliad, but he uses such skill not so much to highlight Homer's strengths (as Aristotle does) and not even to bring out his real weaknesses (as is often the case in Homeric criticism), but rather to undermine his cultural authority and to disprove his side of the story, in order to establish another version under the pretense of finding and defending the historical truth (or better, what he wants his reader to believe as the historical truth).

However, the target of Dio's attack on mythological and cultural tradition is not only the Iliad: the Odyssey is also at issue. In this poem he focuses on the first-person account of Odysseus as a secondary, homodiegetic narrator (scil. in books 9-12). It is an important narrative technique which provides a major formal variation (in order to liven up the account) and also achieves the aim of further removing the story from reality, thus allowing the poet to introduce fanciful and supernatural characters and events in the tale. ${ }^{24}$ Plato was the first to appreciate Odysseus' role as a (temporary) homodiegetic narrator: in Book 3 of the Republic he praises Homer for his capacity to identify with his characters and to make them speak in their own voice ( $\mu$ í $\mu$ joı) $;^{25}$ he also stresses the masterful exploitation of both extradiegetic and metadiegetic narrative in the Odyssey, as he says that "in this form", i.e. alternating the two manners, Homer "has cast the entire narrative of the events that occurred at Troy and in Ithaca, and throughout the Odyssey" ( $\tau \dot{\eta} v$ o $\alpha \lambda \lambda \eta \nu \delta \dot{\eta}$

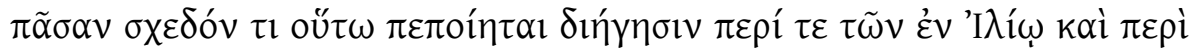

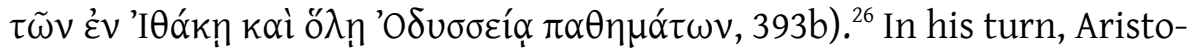
tle praises Homer on the ground that he "has the special merit of being the only poet who rightly appreciates the part he should take himself",

24 Cf. Parry 1994: 1-22; Olson 1995: 43-64; de Jong 2001: 221-27 and passim; Burgess 2017: 95-120.

25 Cf. Marušič 2011: 217-40; Collobert 2013: 463-76.

26 This interpretation of Plato's arguments is supported, among others, by Halliwell 2009: 15-41. 
which means that he does not always "speak in his own person," but "after a few prefatory words, at once he leaves the task of speaking to a man, or a woman, or another personage," thus bringing his epics close to tragedy (Poet. 1460a5-11). ${ }^{27}$ Both Plato and Aristotle, however, focus on Homer's capacity to identify with his characters and make them speak appropriately (in coherence with their own personality): ${ }^{28}$ they substantially appreciate Homer's aptitude for psychological insight; Aristotle goes just a little further on the issue of narrative structure through the comparison between epic and tragedy. ${ }^{29}$

Dio seems to be the first who completely understands the extent of Odysseus' metadiegetic account in a narratological perspective, although it is fairly certain that he found some remarks of this sort in Homeric criticism. ${ }^{30}$ On the other side, he uses this insight to discredit the poet and undermine his tale in the Odyssey, just like he does with the Iliad. Indeed, Dio presents Odysseus' metadiegetic insert as another deceptive expedient (34):

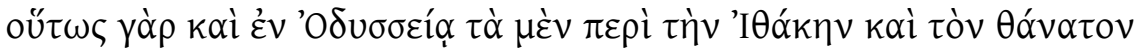

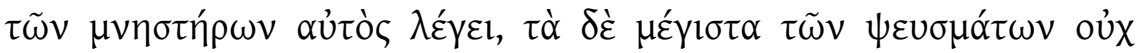

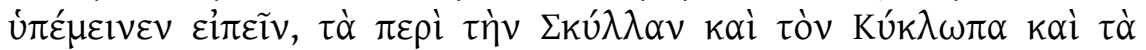

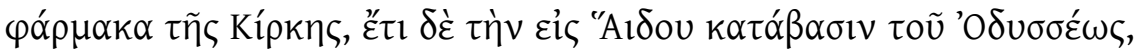

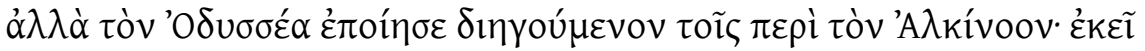

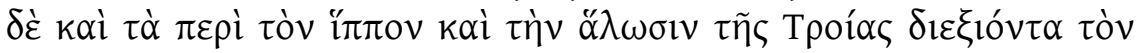

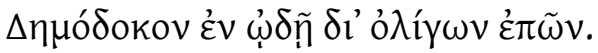

"In the same way, in the Odyssey he tells of events in Ithaca and of the death of the suitors in his own person, but has not dared to mention

27 “O

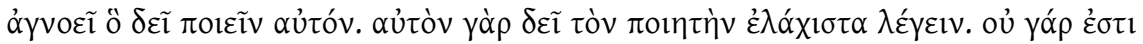

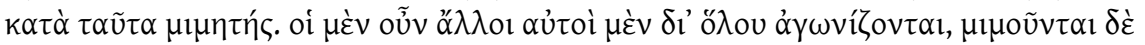

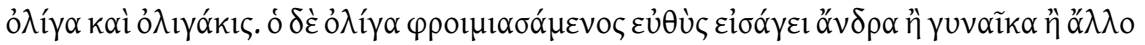

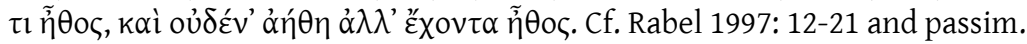

28 On the 'character speech' in Homer's epics cf. Scodel 2004: 45-55; Beck 2008: 162-83.

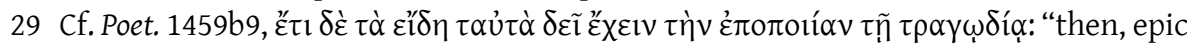
must have the same types of narration as tragedy." Actually epic comes close to tragedy, when events are told by a character rather than by the poet.

30 Cf. Nünlist 2009: 94-135 and especially 116-35. 
the greatest of his falsehoods, notably the story of Scylla, the Cyclops, the magic charms of Circe, and even further, the descent of Odysseus into the Underworld. He makes Odysseus narrate these stories to Alcinous and his court: there too he had Demodocus tell the story of the horse and the conquest of Troy in a song of only a few lines."

Homer is a liar, but he invents so great falsehoods that he does not dare to tell them in first person: then, Odysseus does his "dirty work", so to speak. Dio also notices that, still at Alcinous' court, the same aim is pursued by Homer on a smaller scale with Demodocus' song, recounting the conquest of Troy that is missing in the plot of the Iliad. While Plato and Aristotle appreciate the homodiegetic narrator as a character speaking in his own voice, Dio considers him as the spokesperson for the poet and as an important part of Homer's deceptive strategy. It is also true, however, that Aristotle does not hesitate to recognize Homer's aptitude for

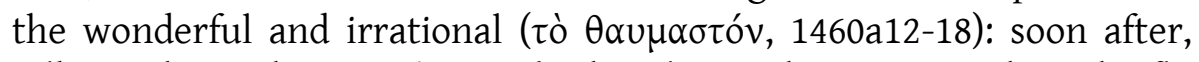
talking about the $\pi \alpha \rho \alpha \lambda \circ \gamma \imath \sigma \mu o$, he claims that "Homer has chiefly taught other poets the art of telling lies skilfully" ( $\delta \varepsilon \delta i ́ \delta \alpha \chi \varepsilon \nu \delta \dot{\varepsilon} \mu \alpha{ }^{\prime} \lambda_{1} \sigma \tau \alpha$

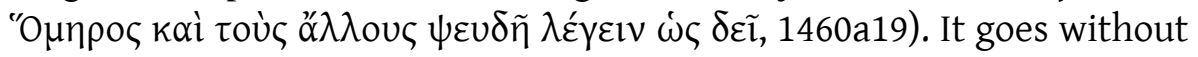
saying that Dio fully agrees with him, at least on this point.

Dio has no doubts on the efficiency of metadiegetic narrative: in fact, he takes it over and uses it to achieve his own ends, pretending to put this expedient at the service of historical truth. Dio claims to have learned his version of the Trojan story from an Egyptian priest: in doing so, he does not follow Homer, but Herodotus, who builds his $\lambda$ óyoc on Egypt by means of eyewitness evidence of local priests (2.99-146). ${ }^{31}$ Actually, Herodotus does not entirely leave the field to these witnesses, hiding behind them to the point of disappearing altogether, as Homer does with Odysseus in books 9-12 of the Odyssey: Herodotus often uses verba dicendi in the account of the priests' information, in order to indicate his presence as their interlocutor and to remind the reader that he is the one

31 Cf. Ellis 2017: 104-29, esp. 105-10. Herodotus' debt to Homer in many respects, including metadiegetic narrative, is recognized by scholars: e.g. de Jong 2002: 245-66. 
listening to the priests and recording their testimony. ${ }^{32}$ He resorts to this expedient to ensure the reliability of the $\lambda$ óyos (besides the purpose of variatio).

Dio's speech is on the same line as Herodotus, insofar as it maintains the co-presence of the author's own voice (as primary narrator) and as a witness (as secondary narrator). Dio goes even further, given that he does not limit the role of the Egyptian priest to providing reliable information: Dio also makes him utter disparaging and ironical comments about the Greek people, which constitute the audience, or at least a part of the audience, of the speech. ${ }^{33}$ For instance, through the voice of the priest, he accuses the Greeks to be "ignorant and loudmouthed" (39.2-3), and stigmatizes their "love of pleasure" (42.1-5):

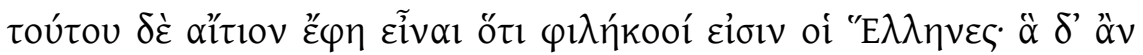

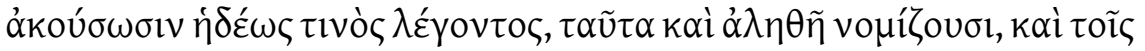

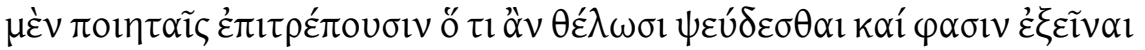

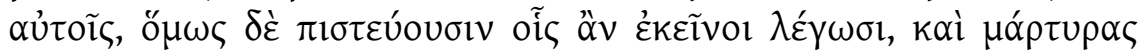

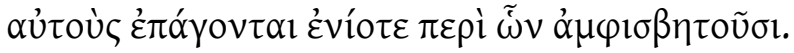

"He claimed that it happened (scil. Homer's success in deception) because of Greek love of pleasure: they easily believe to be true whatever they delight to hear from anyone's lips; they allow poets to tell any untruth they wish, and they consider such prerogative as poetic license. Yet they trust them in everything they say and even quote their words at times as evidence in matters of dispute."

Dio reuses therefore Herodotus' expedient in an innovative way, not only as a guarantee of reliability for his version (against Homer's tale), but

32 On the difference between "secondary narrators" and "reported narrators" cf. de Jong 2004: 107-10); on the alternance of the former and the latter in Herodotus'

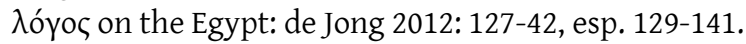

33 In the beginning (4) Dio addresses his speech to the Trojans (ớv $\delta \rho \varepsilon \varsigma$ 'I $\mathrm{\lambda} 1 \varepsilon \tilde{\mathrm{l}} \varsigma$ ), but shortly after (6.1-2) he recognises that it "will be necessarily given in other places

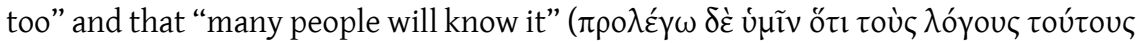

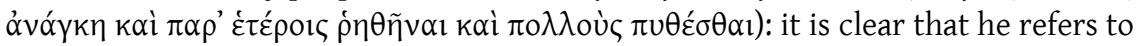
Greeks, to which he belongs in terms of language and culture. 
also as a clever strategy to convey a message uncomfortable to the audience: the priest's evidence works as an 'alternative' voice that enters the account and articulates what the author cannot say in the first person. ${ }^{34}$ Accordingly, it seems clear that Dio follows both Homer and Herodotus, or better, he corrects Homer with Herodotus' help. It is nevertheless true that the idea of attributing an awkward statement to a "substitute" or "stand-in" for the poet ultimately stems from the Odyssey, or rather from Dio's individual interpretation of Odysseus' role in this poem. Dio does exactly what he blames Homer for.

Dio thus achieves a systematic denial of Homer's tale, largely corresponding to the traditional version of the legend; ${ }^{35}$ but this process is not an end in itself: the pars destruens is aimed at discovering the historical truth, which is the pars construens of the Trojan discourse. Hence, from a narratological perspective, Dio's reworking of the story generates a problematic doubling of tales concerning the same subject, i.e. Homer's fiction and the true version, which co-exist within the Trojan discourse. ${ }^{36}$ The true version is built with the story elements forming the plot of the Iliad, which is deconstructed and reassembled in a brand new pattern. The major point of Homer's narrative is reversed: it is Hector who kills Achilles, and not the opposite. Likewise, the main events of the myth before and after the time span of the Iliad are overturned: the marriage between Helen and Paris takes the place of the abduction of the latter as the leading cause of hostility; the victory of the Trojans over the Greeks becomes the outcome of the war.

However, this is not only an entertainment: Dio's reworking of the myth is not a mere exercise in rhetoric, and not pure virtuosity, as some

34 Actually, Herodotus already attributes to Egyptian priests unflattering references to the cultural baggage of the Greeks, most notably on the Trojan myth (in particular 2.118.1). Cf. Saïd 2012: 87-105.

35 As for Patroclus, I call "the traditional version" the one established by Homer and almost universally endorsed from the Iliad onwards, rather than the original (preHomeric) legend, in which Achilles was paired with Antilochus. For an overview of neo-analytic criticism about this subject cf. Burgess 1997: 1-19; Scafoglio 2017: 41-47 and passim.

36 Cf. Phillips 2012: 95-106, esp. 98-99, discussing Hunter 2009: 43-61. 
scholars believe. ${ }^{37}$ The supposed recovery of historical truth is full of consequences. The legitimate wedding of Paris and Helen relieves not only the Trojans, but also the gods, of the responsibility for the war: there was no judgment of Paris, no abduction of Helen, no vengeance of the goddesses. The responsibility lies with the Greeks, but the most important consequence is the exposure of the real underlying causes of the war, that is the appetite for power and wealth, the wish to take over by force a thriving and prosperous city (64.1-4):

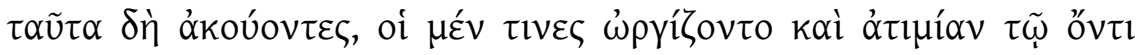

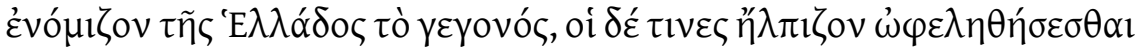

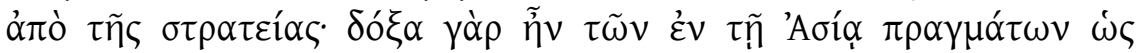

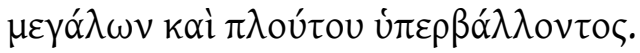

"Some < suitors of Helen> were furious at hearing < about her marriage with Paris>: they felt it was a shame to Greek people, while others expected to profit from war: there was rumor, indeed, that great wealth and a lot of assets were in Asia."

Dio seems to suggest that this is the real reason not only for the Trojan War, but for all the wars; and probably he is not wrong.

The murder of Achilles by Hector calls for a reflection on the Homeric conception of heroism, and perhaps on heroism in general. What is heroism? It seems to be a construction, or even a deception, carefully built to make the war look good, noble, beautiful, and appealing. Indeed, Achilles is the hero par excellence: he is the model hero not only in the Homeric epics, but in the entire literary tradition that starts from Homer. ${ }^{38}$ Yet his best deed turns out to be a fake.

The rewriting of the end of the war, with the victory of the Trojans, can be interpreted as a restoration of justice: the right outcome of a wrong process. It can be interpreted as the final evidence of a highminded and often neglected ideal: war, unfairness and violence do not

37 E.g. Szarmach 1978: 195-202; del Cerro Calderón 1997: 95-106; Bolonyai 2001: 25-34. Contra, Kindstrand 1973: 141-62; Desideri 1978: 431-34, 496-503; Gangloff 2006: 12236; Scafoglio 2016.

38 Cf. Schein 1984: 89-167; Callen King 1987: esp. 1-45; Nagy 2005: 71-89. 
bring anything but trouble and defeat. This also leads to a reflection on history, which runs the risk of turning out to be a construction too: an ideological and propagandist construction, pursuing the aim of rehabilitating and celebrating the war, hiding its real outcome and consequences.

Thus, the analysis of Homeric narrative techniques conducted by Dio in his Trojan Discourse is not merely a rhetorical exercise (in the spirit of virtuosity and self-complacency that is typical of the Second Sophistic), as some scholars believe. ${ }^{39}$ Dio develops critical skills and tools preluding (in embryonic form, as I said) to modern narratology, in order to disprove the traditional version of the Trojan legend, based on the Homeric epics - but he does it for an ethical purpose, notably to reject the bellicose ideology arising from these poems. He realizes a kind of tendentious (or 'perverted', I would say) criticism that is the first step of a rework of Homeric narrative, a rework aimed at establishing a new set of values and ideals - first of all, the ideal of peace.

39 E.g. Szarmach 1978: 195-202; Bolonyai 2001: 25-34. Contra, Desideri 1978: 431-34, 496503. 


\section{BIBLIOGRAPHY}

Amato, E. 2014. Traiani praeceptor. Studi su biografia, cronologia e fortuna di Dione Crisostomo. Besançon.

Arnould, D. 1990. Le rire et les larmes dans la littérature grecque d'Homère à Platon. Paris.

Bär, S. 2018. 'Diktys und Dares vor dem Hintergrund des zweitsophistischen Homerrevisionismus' in G. Brescia, M. Lentano, G. Scafoglio \& V. Zanusso (eds.) Revival and Revision of the Trojan Myth: Studies on Dictys Cretensis and Dares Phrygius. Hildesheim-New York, 151-76.

Beck, D. (2008). 'Character-Quoted Direct Speech in the Iliad' Phoenix 62, 162-83.

Bernabé A. 1987. Poetae epici Graeci. Testimonia et fragmenta. Leipzig. Bolonyai, G. 2001. "The uses of progymnasmata: the case of "refutations" and Dio's Trojan Oration' AAntHung 41, 25-34.

Briand, M. 2015. 'L'Homère paradoxal de Lucien. Un dialogue, entre imitation et satire' in S. Dubel, A.-M. Favreau-Linder \& E. Oudot (eds.) À l'école d'Homère. La culture des orateurs et des sophistes. Paris, 163-72.

Brink C.O. 1971. Horace on Poetry: The Ars Poetica. Cambridge.

Burgess, J. 1997. 'Beyond Neo-Analysis: Problems with the Vengeance Theory’ AJPh 118, 1-19.

Burgess, J. 2017. 'The Apologos of Odysseus: Tradition and Conspiracy Theories' in C. Tsagalis \& A. Markantonatos (eds.) The Winnowing Oar. New Perspectives in Homeric Studies. Berlin \& Boston, 95-120.

Callen King, K. 1987. Achilles: Paradigms of the War Hero from Homer to the Middle Ages. Berkeley-Los Angeles.

Carli, S. 2010. 'Poetry is more Philosophical than History: Aristotle on Mimesis and Form' Review of Metaphysics 64, 303-36.

Cavarero, A. 2002. 'The Envied Muse: Plato versus Homer' in E. Spentzou \& D. Fowler (eds.) Cultivating the Muse. Oxford, 47-67.

Collobert, C. 2013. 'La littérarité platonicienne : instances et modes narratifs dans les dialogues' Revue de Métaphysique et de Morale 4, 463-76.

Davies, M. 1988. Epicorum Graecorum fragmenta. Göttingen.

Davies, M. 1989. The Greek Epic Cycle. Bristol.

De Jong, I. 2001. A Narratological Commentary on the Odyssey. Cambridge. 
De Jong, I. 2002. 'Narrative unity and units' in E. Bakker, I. de Jong \& H. van Wees (eds.) Brill's Companion to Herodotus. Leiden \& Boston, 245-66.

De Jong, I. 2004. 'Herodotus' in I. de Jong, R. Nünlist \& A. Bowie (eds.) Narrators, Narratees and Narratives in Ancient Greek Literature. Leiden \& Boston, 101-14.

De Jong, I. 2012. 'The Helen logos and Herodotus' fingerprint', in E. Baragwanath \& M. de Bakker (eds.) Myth, Truth, and Narrative in Herodotus. Oxford, 127-42.

Del Cerro Calderón, G. 1997. 'Las claves del Discurso Troyano de Dión de Prusa' Habis 28, 95-106.

Desideri, P. 1978. Dione di Prusa. Un intellettuale greco nell'impero romano. Messina \& Firenze.

Desideri, P. 1980. 'Religione e politica nell'Olimpico di Dione' Quaderni storici 15, 141-61.

Desideri, P. 2000. 'Dione di Prusa uomo religioso' ARYS 3, 203-14.

Dihle, A. 1970. Homer-Probleme. Opladen.

Edwards, M.W. 1992. 'Homer and Oral Tradition: The Type-Scene' Oral Tradition 7, 284-330.

Ellis, A. 2017. 'Fictional Truth and Factual Truth in Herodotus' in L. Hau \& I. Ruffell (eds.) Truth and History in the Ancient World: Pluralizing the Past. London, 104-29.

Else, G. F. 1957. Aristotle's Poetics: The Argument. Cambridge.

Erbse, H. 1983. 'Ilias und Patroklie' Hermes 111, 1-15.

Fantuzzi, M. 2015. 'The aesthetics of sequentiality and its discontents' in M. Fantuzzi \& C. Tsagalis (eds.) The Greek Epic Cycle and its Ancient Reception: A Companion. Cambridge, 405-29.

Favreau-Linder, A.-M. 2013. 'Citations poétiques et stratégies rhétoriques: la parole poétique comme instrument de mise en scène du sophiste' in H. Vial (ed.) Poètes et orateurs dans l'Antiquité. Mises en scène réciproques. Clermont Ferrand, 375-97.

Fornaro, S. 2000. 'Accuse e difese d'Omero: Platone nell'orazione undicesima di Dione Crisostomo’ Eikasmos 11, 248-65.

Fornaro, S. 2002. 'Omero cattivo storico: l'orazione XI di Dione Crisostomo' in F. Montanari \& P. Ascheri (eds.) Omero tremila anni dopo. Roma, 547-60. 
Gangloff, A. 2006. Dion Chrysostome et les mythes. Hellénisme, communication et philosophie politique. Grenoble.

Halliwell, F.S. 2009, 'The theory and practice of narrative in Plato' in J. Grethlein \& A. Rengakos (eds.) Narratology and Interpretation. The Content of Narrative Form in Ancient Literature. Berlin \& Boston, 15-41.

Hart, J. 2012, Fictional and Historical Worlds. New York.

Heath, M. 1991. 'The Universality of Poetry in Aristotle's Poetics' CQ 41, 389-402.

Hunter R. 2009. 'The Trojan Oration of Dio Chrysostom and Ancient Homeric criticism' in J. Grethlein \& A. Rengakos (eds.) Narratology and Interpretation. The Content of Narrative Form in Ancient Literature. BerlinNew York, 43-61.

Jones, C.P. 1978. The Roman World of Dio Chrysostom. Cambridge, MA \& London.

Kim, L. 2010. Homer between History and Fiction in Imperial Greek Literature. Cambridge.

Kindstrand, J.F. 1973. Homer in der zweiten Sophistik. Uppsala.

Kirk, G.S. 1990. The Iliad: A Commentary. Vol. II: Books 5-8. Cambridge.

Kullmann, W. 1960. Die Quellen der Ilias. Wiesbaden.

Lacore, M. 2003. 'La théologie d'Homère jugée par Platon' in J. Laurent (ed.) Les dieux de Platon. Caen, 79-95.

Marušič, J. 2011. 'Poets and Mimesis in the Republic' in P. Destrée \& F.-G. Herrmann (eds.) Plato and the Poets. Leiden \& Boston, 217-40.

Montanari F. 1998. 'Antichi commenti a Omero. Alcune riflessioni' in F. Montanari (ed.) Omero. Gli aedi, i poemi, gli interpreti. Firenze, 1-17.

Murray, P. 1996. Plato on Poetry: Ion, Republic 376e-398b, Republic 595-608b. Cambridge.

Nagy, G. 2005. 'The Epic Hero' in J.M. Foley (ed.) A Companion to Ancient Epic. Oxford, 71-89.

Nünlist, R. 2009. The Ancient Critic at Work. Terms and Concepts of Literary Criticism in Greek Scholia. Cambridge.

Olson, S.D. 1995. Blood and Iron: Stories and Storytelling in Homer's Odyssey. Leiden.

Parry, H. 1994. 'The Apologos of Odysseus: Lies, All Lies?' Phoenix 48, 1-20. Pasquali, G. 1952. Storia della tradizione e critica del testo. 2nd ed. Firenze. 
Phillips, T. 2012. 'J. Grethlein and A. Rengakos (eds.), Narratology and Interpretation. The Content of Narrative Form in Ancient Literature. 2009' Ancient Narrative 10, 95-106.

Priestley, J. 2014. Herodotus and Hellenistic Culture: Literary Studies in the Reception of the Histories. Oxford.

Rabel, R.J. 1997. Plot and Point of View in the Iliad. Ann Arbor.

Rengakos, A. 1999. 'Spannungsstrategien in den homerischen Epen' in J.

N. Kazazis \& A. Rengakos (eds.) Euphrosyne. Studies on Ancient Epic and its Legacy in Honor of D.N. Maronitis. Stuttgart, 308-38.

Richardson, N. 1992. 'Aristotle's Reading of Homer and its Background' in R.W. Lamberton \& J. Keaney (eds.) Homer's Ancient Readers. Princeton, 30-40.

Richardson, N.J. 1994. 'Aristotle and Hellenistic Scholarship' in F. Montanari (ed.) La Philologie grecque à l'époque hellénistique et romaine. Vandœuvres-Genève, 7-38.

Rosenmeyer, T.G. 1982. 'History or Poetry? The Example of Herodotus' Clio 11, 239-59.

Rudd N. 1989. Horace, Epistles Book II and Epistle to the Pisones (Ars Poetica). Cambridge.

Saï, S. 2012. 'Herodotus and the Myth of the Trojan War' in E. Baragwanath \& M. de Bakker (eds.) Myth, Truth, and Narrative in Herodotus. Oxford, 87-105.

Scafoglio, G. 2007. 'Aristotele e il ciclo epico. Una nota a Poet. 1459a37-b7' RHT 2, 287-98.

Scafoglio, G. 2016. 'Il riuso del testo omerico e del ciclo epico nel Troiano di Dione. Osservazioni metodologiche ed esemplificazione' in E. Amato, G. Ventrella \& L. Thévenet (eds.) Dion de Pruse : l'homme, son œuvre et sa postérité. Hildesheim \& New York, 435-63.

Scafoglio, G. 2017. Ajax. Un héros qui vient de loin. Amsterdam.

Schadewaldt, W. 1951. Von Homers Welt und Werk. 2nd ed. Stuttgart.

Schein, S.L. 1984. The Mortal Hero. An Introduction to Homer's Iliad. Berkeley \& Los Angeles.

Scodel, R. 2004. 'The Story-teller and his Audience' in R. Fowler (ed.) The Cambridge Companion to Homer. Cambridge, 45-55.

Seeck, G.A. 1990. 'Dion Chrysostomos als Homerkritiker (Or. XI)' RhM 133, 97-107. 
Stroud, T.A. \& E. Robertson. 1996. 'Aristotle's Poetics and the Plot of the Iliad' CW 89, 179-96.

Swain, S. 1996. Hellenism and Empire. Language, Classicism and Power in the Greek World, A.D. 50-250. Oxford.

Szarmach, M. 1978. 'Le Discours Troyen de Dion de Pruse' Eos 66, 195-202.

Vagnone, G. 2003. Dione di Prusa, Troiano (Or. XI). Roma.

Van Nuffelen P. 2011. Rethinking the Gods: Philosophical Readings of Religion in the Post-Hellenistic Period. Cambridge.

Ward, A. 2013, Socrates and Dionysus: Philosophy and Art in Dialogue. Cambridge.

West, M.L. 2003. Greek Epic Fragments. Cambridge, MA \& London.

Young, D.C. 1983. 'Pindar, Aristotle and Homer: A Study in Ancient Criticism' ClAnt 2, 156-70.

Zeitlin, F.I. 2001. 'Visions and revisions of Homer in the Second Sophistic' in S. Goldhill (ed.) Greek Identity in the Second Sophistic. Cambridge, 195266.

Giampiero Scafoglio

Université de Nice Sophia Antipolis

Giampiero.Scafoglio@unice.fr 